\title{
sciendo
}

Research Article

(C) 2019 Deputatova et.al. This is an open access article licensed under the Creative Commons Attribution-NonCommercial-NoDerivs License (http://creativecommons.org/licenses/by-nc-nd/3.0/).

\section{Extra-Linguistic Features of the Southern Dialect of American English in the Novel of Harper Lee "Go Set a Watchman"}

\author{
Nataliya Anatolevna Deputatova \\ Diana Rustamovna Sabirova
}

\author{
Liya Faridovna Shangaraeva
}

Anel Nailevna Sabirova

Olga Valerevna Akimova

Kazan Federal University

Doi: 10.2478/jesr-2019-0029

\begin{abstract}
The article discusses the multi-level linguistic features of the variations of the American English in the United States under the influence of territorial isolation, which forms the structure and functional use of the language. In the USA an extensive material on regional types of pronunciation has been collected in the fields of sociolinguistics and dialectology while the variability of English speech on the territory of the United States of America remains practically unexplored. In this article the extra-linguistic features, namely, territorial peculiarities of the southern dialect are considered in combination with the features of the dialect of the South Mountain region and the dialect of South Coast area on the example of the novel "Go Set a Watchman" by Harper Lee. Phonetic, grammatical and lexical peculiarities of the southern dialect have been studied. The examples from the book enabled us to see the specific nature of the dialect of the Southern United States. We have also compared phonetic, lexical and grammatical features of this dialect with the literary English language and saw huge differences. Having analyzed the grammatical peculiarities of the southern dialect, for example, we conclude that the most common grammatical error of the local population is the incorrect formation of general questions, the use of the tense forms of the verbs and the absence of auxiliary verbs in the sentences.
\end{abstract}

Keywords: language, linguistics, dialect, variability, extra-linguistic features, pronunciation, territorial isolation

\section{Introduction}

In this article we have considered the variability of Southern English in the USA in response to territorial remoteness, which forms language structure and functional using. Any language is perceived as a nation's cultural phenomena. Variability as a feature of language system is the brightest demonstration of its evolution and takes place on every language level (phonetic, grammatical and lexical), conforming to the specificity of every level [Cheshire, 2002].

The purpose of this work is studying of speech variability (including phonetic, grammatical and lexical levels) according to its extra-linguistic features, specifically, territorial remoteness [Bernstein, 2003]. Territorial isolation is inherent in each representative of a particular region. Everyone knows that the speech of the British living in London specifically differs from the speech of the inhabitants of Bristol, Edinburgh and Cardiff, and the speech of the New Yorkers differs from the characteristics of the speech from Sydney and Auckland [Cassidy, 2002; Yazdekhasti et al, 2015;].

Data for study of Southern American English and its' grammatical features was the novel "Go 
Set a Watchman" by Harper Lee.

The main principles and conclusions of this research can be used for practical purposes - for teaching students majoring in linguistics and interpretation. In addition, the results of this research can be taken into account for the elaboration of theoretical courses in Sociolinguistics and Theoretical Grammar.

\section{Methods}

While writing this article the following methods were used: theoretical analysis of literature sources; descriptive method; method of classification; structural and semantic method; comparative analysis method.

\section{Results and Discussion}

At the present stage of development, the variability of speech is of great interest to linguists. It should be noted that the variability of speech is influenced by extra-linguistic factors such as territorial isolation, social stratification of speakers and different spheres of human activity and the situations [Labov, et al. 2006; Iravani et al, 2015].

We will consider extra-linguistic, specifically, territorial features of Southern American English based on the novel "Go Set a Watchman" by Harper Lee. Geographically this dialect extends to the following states: Arkansas, Missouri, Mississippi, Alabama, Kentucky, Tennessee, West Virginia, Virginia, Texas, Oklahoma, Arkansas, Louisiana, Mississippi, Alabama, Georgia, Florida, South Carolina, North Carolina, Virginia, Maryland and Delaware [Hazen et al. 2004; Pussyrmanov et al, 2018].

K. Salvuchchi's classification is adopted as the basis in the article since it closely reflects the variability of the territorial United States. This classification synthesizes the results of linguistic researches of such prominent linguists as Hans Kurata, Charles Thomas, Raven McDavid, Fredrik Cassidy, Craig Carver and William Labov [Collins and Mees, 2013; Singh et al., 2018].

After analyzing the text of the novel, we distinguished phonetic, grammatical and lexical features of the Southern dialect and compared them with the peculiarities of the given dialect [Herman and Herman, 1997].

\subsection{Phonetic features}

Sound reduction $/ \eta /$ at the end of words ending in "-ing". In the text there are 68 examples confirming this feature. For example, "Everything's rosy for a while, but the men get tired and their wives start yellin' again and around it goes." [Lee, 2015: 48]. "He on the back porch laughin'?" [Lee, 2015: 70]. "You and Hank mollockin' around in the river-hah! - ought to be ashamed of yourselves-disgrace to the family-have fun?" [Lee, 2015: 90]. "Well I ain't gonna tell you. You can just sit there and eat your ice cream and try to figure out who I am, and if you can I'll give you another helpin' free of charge" [Lee, 2015: 112].

Sound reduction / $ठ /$ in the word them - 'em. There are 82 examples in the text. For example, "No, but I can give 'em a run for their money. The Courthouse Crowd are pretty well asleep at the switch now, and a hard campaign might just beat 'em." [Lee, 2015: 77]. "Yes sir. Reckon we ought to take 'em through town on a pole?" [Lee, 2015: 87].

Sound reduction / $\mathrm{d} /$ in the word and. IAn'/ - one example in the text of the work. For example, "-an' that's all there is to it. What's the matter, Jean Louise? You're white as a hain't. Ain't scared'ja, have I?" Ada Belle smirked." [Lee, 2015: 129].

Sound reduction / $\partial$ / in such a word as around / ə'raund /. This feature of the sound reduction / $ə$ / at the beginning of words we can see in the text one time. For example, "Cousin Joshua was 'round the bend, don't forget that." [Lee, 2015: 34].

The word no is pronounced / na: /. In the text of the book the word "naw" occurs one time. For example, "Naw sir, Mr. Finch," was her slow reply. "Zeebo, he been goin' around enjoyin' other women. He doesn't enjoy me none, and I don't want no man who don't enjoy his wife." [Lee, 2015: 
157].

Pronunciation of the word because as / 'koz / instead of the correct variant / br' koz/. In the text of the book the word cause occurs one time. For example, "Because things started for you a mite early, and you didn't seem to take to it so much, and we didn't think you'd take to the rest of it any better. Mr. Finch said wait a while till you got used to the idea, but we didn't count on you finding out so quick and so wrong, Miss Scout." [Lee, 2015: 139].

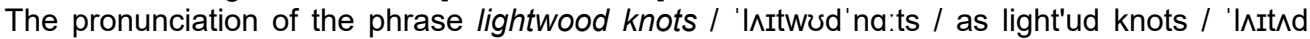
'na:ts /. In the text of the book this phrase occurs two times. For example, "Make them feel helpless, especially when you know they can pick up a load of light'ud knots with no trouble." [Lee, 2015: 47]. "... black as burnt light'ud knots... bribed the Supreme Court... decent white Christians... was Jesus crucified for the nigger..." [Lee, 2015: 110].

“The Curse. Curse o' Eve. If Eve hadn't et the apple we wouldn't have it. You feel bad?" [Lee, 2015: 127]. In this example, we can observe the pronunciation of the word ate / ert /, as et / et /.

"You're sort of 'hind f'omus, Miss Scout. You sort of haven't caught up with yourself... now if you'd been raised on a farm you'da known it before you could walk, or if there'd been any women around-if your mamma had lived you'da known it-" [Lee, 2015: 138]. In this example, we observe a reduction of the sounds / b/, / $\mathrm{i}$ / and / $\mathrm{r} /$ in the phrase behind from us / bI'haind from $\Lambda \mathrm{s} /$, which is pronounced as 'hind f'omus / 'haindf'omes /.

Also, in this example, we see a reduction of colloquial form - / ju:'da / instead of / ju: wod hæv I, which occurs 4 times in the text of the work. A similar reduction of the he'da / hi:'da / colloquial form occurs once in this text. "I don't think anybody noticed it, Scout. Listen, Jem danced with you just before I did, and if he'd noticed it he'da certainly told you." [Lee, 2015: 214].

"You have had what Mr. Burgess would call "The 'Orrors," she told it." [Lee, 2015: 141]. In this example, we see the reduction of sounds - / 'orəs / instead of the correct version / 'horəs /.

"Yessum," the big man said. "But it doesn't look like there's anything. Frank, he sho' killed him, and there's nothing nobody can do. Mr. Finch, he can't do nothing about sump'n like that. Is there anything I can do for you while your home, ma'am?"' [Lee, 2015: 160]. In this example, the word

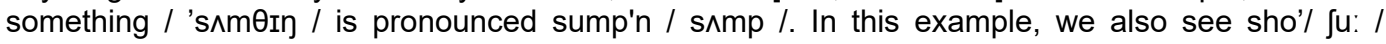
instead of should have / fud hæv /. In this example, the reduction of finite sounds in the word should is traced and the word have is omitted.

"Mr. Finch called this morning and said he was bringing the preacher and his wife home for dinner. I yelled till I was blue in the face for you all. Why'nt you answer me?" [Lee, 2015: 68]. In this example, the reduction of sounds is traced in the phrase Why didn't you before Why'nt when asking a special question.

\subsection{Lexical features}

Ain't is an abbreviation for such constructions as "am not", "is not", "has not", and "have not" in colloquial English. In some dialects, this structure replaces the following constructs - "do not", "does not", "did not". As the Cambridge English Dictionary declares: "The use of ain't was widespread in the 18th century, typically as a contraction for am not. It is still perfectly normal in many dialects and informal speech in both Britain and North America. Today, however, it does not form part of standard English and should never be used in formal or written contexts" [8]. There are 14 examples from the text of the work with the use of "ain't". For example, "Maycomb's changed, ain't it?" [Lee, 2015: 112]. "Well I ain't gonna tell you. You can just sit there and eat your ice cream and try to figure out who I am, and if you can I'll give you another helpin' free of charge." [Lee, 2015: 122].

To reckon = to think, or to believe (believe, count) is found in the text of the work 14 times. For example, "Never did have a sense of humor, pompous old catfish. That's just what he is: whiskers here and here and a catfish mouth. I reckon he thinks my living alone in New York is ipso facto living in sin." [Lee, 2015: 25]. "Yes sir. Reckon we ought to take 'em through town on a pole?" [Lee, 2015: 87]. Verbs take a special place in the entire system of language and are an important object of study [Akhmetova, et al. 2019].

Gonna $=$ going to (to gather, intend). Examples from the text of the work with the use of the 
word "gonna" - 16. For example, "Atticus, l'm throwing it at you and I'm gonna grind it in: you better go warn your younger friends that if they want to preserve Our Way of Life, it begins at home. It doesn't begin with the schools or the churches or anyplace but home. Tell 'em that, and use your blind, immoral, misguided, nigger-lovin' daughter as your example. Go in front of me with a bell and say, 'Unclean!' Point me out as your mistake. Point me out: Jean Louise Finch, who was exposed to all kinds of guff from the white trash she went to school with, but she might never have gone to school for all the influence it had on her. Everything that was Gospel to her she got at home from her father. You sowed the seeds in me, Atticus, and now it's coming home to you -" [Lee, 2015: 248]. "I'm gonna get in this car and drive it to Maycomb Junction and sit there until the first train comes along and get on it. Tell Atticus if he wants his car back, he can send after it." [Lee, 2015: 260].

Yonder = over there. In the text of the work is found 4 times. For example, "We were all the time you were hexed but we're not anymore," said Jem. "Professor Wiggins is staked out in a hut over yonder and we've got to get him -" [Lee, 2015: 59]. "When the saved of earth shall gather over on the other shore, and the roll is called up yonder, I'll be there." [Lee, 2015: 64].

Wanta = want to. The word "wanta" is found in the text of the work one time. For example, "Don't wanta," said Jean Louise." [Lee, 2015: 127].

$D a=$ could. This word is found in the text of the work 5 times. For example, "Calpurnia frowned and sought an answer. "You're sort of 'hind f'omus, Miss Scout. You sort of haven't caught up with yourself... now if you'd been raised on a farm you'da known it before you could walk, or if there'd been any women around-if your mamma had lived you'da known it-"' [Lee, 2015: 138]. 'Yessum. You'da seen things like your daddy kissin' your mamma and you'da asked questions soon as you learned to talk, I bet." [Lee, 2015: 138].

Yessum = yes, Ma'am (polite expression of consent or approval towards a woman). It is found in the text of the work 13 times. For example, "Oh-yessum," she said, "but wait a minute, Aunty. I left New York stockinged, gloved, and shod. I put on these right after we passed Atlanta." [Lee, 2015: 21].

Looka! = look out! (look). It is found in the text of the work one time. For example, "Guessed my name yet? Why looka yonder, you've wasted your ice cream." [Lee, 2015: 120].

Gimme = give me. It is found in the text of the work one time. For example, "Cut it out, Aunt Rachel!" burbled Dill, his head half under water. "Gimme a chance!" [Lee, 2015: 67].

My hind foot is an expression used to negate something. "-and anybody who thinks different's either a Communist or might as well be one. Passive resistance, my hind foot...", [Lee, 2015: 176].

Hon = honey, my dear. "He's doing beautifully, hon. You know he was made Man of the Year by the Kiwanis Club. They gave him a lovely scroll." [Lee, 2015: 33].

Dudn't = mixing "didn't" and "doesn't". Consequently, it covers both the past and the present. "If he dudn't whale the tar out of both of you, I will,' Calpurnia promised." [Lee, 2015: 69].

$H n h=$ what. It is found in the text of the work one time. For example, "Jean Louise sat up in bed. "Hnh?" " [Lee, 2015: 85].

Howdy do = how do you do (how are you? Hello! Hello!). Occurs in the work one time. "Howdy do, Miss Jean Louise. We didn't know you was home." [Lee, 2015: 156].

A tall $=$ at all (in general). It occurs in the work one time. "He has a childlike faith in the integrity of civil servants and he seems to think Congress corresponds to their aristocracy. No understanding of American politics a-tall." [Lee, 2015: 18].

\subsection{Grammatical features}

After a thorough analysis of the grammatical features of the Southern dialect of the United States of America based on the material of Harper Lee's "Go Set a Watchman", we can say that one of the most remarkable features from a grammatical point of view is the incorrect formulation of general questions. Text examples, "Want to drive?" [Lee, 2015: 11]. In this sentence, you can observe the omission of the auxiliary verb Do, which, by the grammatical rule of asking the general question, should be. The correct version of this interrogative sentence would be: "Do you want to drive?"

"Tired of New York?" [Lee, 2015:13]. In this question we also observe the absence of the verb 
to be. And, the correct version of this question would sound like this: "Are you tired of New York?"

"You remember how it used to look?" [Lee, 2015: 23]. In this example of the general question, we already see the absence of the verb do, since personal pronoun you have the second person singular form. It would be correct to ask the question like this: "Do you remember how it used to look?"

"Didn't he used to play the jug" [ Lee, 2015: 153]. In this example, we see the misuse of the form Past Simple. The correct option should be: "Didn't he use to play the jug?"

"He on the back porch laughin'!" [Lee, 2015: 70]. And again, we observe the omission of the verb to be. The correct option is: "He is on the back porch laughin'!"

One more grammatical feature of the South dialect is the misuse of the tense form + omission of the auxiliary verb is. "She taking it mighty hard, Miss Jean Louise. Frank, he never had any trouble before ..." [Lee, 2015: 157]. Since there is the word never indicating to us the time that should be used here, we can say that the Present Perfect Tense should be used in this sentence. And, the correct version of this sentence would sound like this: "She is taking it mighty hard, Miss Jean Louise. Frank, he has never had any trouble before..."

"Don't sound it..." [Lee, 2015: 145]. In this phrase, instead of the auxiliary verb doesn't used don't, which does not correspond to the grammatical rule. After all, with the personal pronoun of the third person singular we use the auxiliary verb doesn't. The correct option is: "Doesn't sound it ..."

In the following example, we also see an error in the use of the auxiliary verb do and does, since the subject is expressed by the noun in the third person singular, according to the rules it should be does: "But it doesn't look like there's anything. Frank, he sho' killed him, and there's nothing nobody can do. Mr. Finch, he can't do nothing about sump'n like that. Is there anything I can do for you while your home, ma'am?" [Lee, 2015: 160]. The correct option is: "But it doesn't look like there's anything. Frank, he sho' killed him, and there's nothing nobody can do. Mr. Finch, he can't do nothing about sump'n like that. Is there anything I can do for you while your home, ma'am?"

"She barely heard Calpurnia talking: "Frank, he does wrong... he pays for it... my grandson. I love him... but he goes to jail with or without Mr. Finch..."' [Lee, 2015: 157]. In this example, there is a mistake in the use of tense form. The verb does must be used in Past Simple Tense, since the action has already taken place. The expressions "... he pays for it ..." and "... but he goes to jail ..." should be used in Future Simple Tense. The correct option is: "She barely heard Calpurnia talking: "Frank, he did wrong... he will pay for it... my grandson. I love him... but he will go to jail with or without Mr. Finch..."”

"Want me to run get Bennett?" [Lee, 2015: 56]. In this case, we can see the incorrect formulation of the special question, and also there are verbs that have no connection with each other. Particle to is missed in the question. The correct options are: "Do you want me to run to get Bennett?" или "Do you want me to run and get Bennett?"

"Who've you invited?" [Lee, 2015: 165]. In this example, the incorrect formulation of the special question is evident. The correct structure of the question should be like this: "Whom have you invited?"

"He did, did he?" [Lee, 2015: 97]. Here we observe an incorrect form of the tag question. The correct question would be: "He did, didn't he?"

\section{Summary}

Having considered all the phonetic and lexical features of the Southern American English dialect based on the novel "Go Set a Watchman", we can make the following diagrams. 


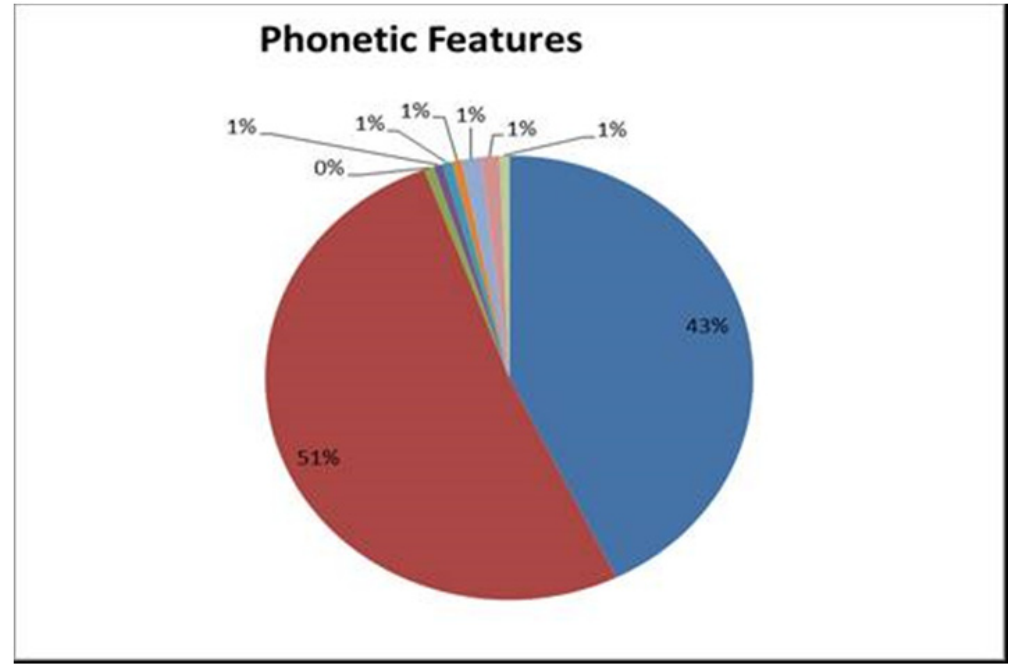

Fig. 1. Phonetic features of Southern American English on the example of the novel "Go Set a Watchman".

$43 \%$ Reduction of the sound / $\mathrm{n} /$ at the end of words

$51 \%$ Reduction of the sound / $/$ / in the word them

$0 \%$ Reduction of the sound / $d /$ in the word and

$1 \%$ Reduction of the sound / $ə /$ in the word around

$1 \%$ The word no is pronounced as / na: /

$1 \%$ The pronunciation of the word because as / 'koz /

$1 \%$ The pronunciation of the word combination lightwood knots as / 'I $\wedge$ It $\wedge$ d 'na:ts /

$1 \%$ Reduction of colloquial forms / ju:'da /

$1 \%$ Reduction of colloquial forms / hi:'da /

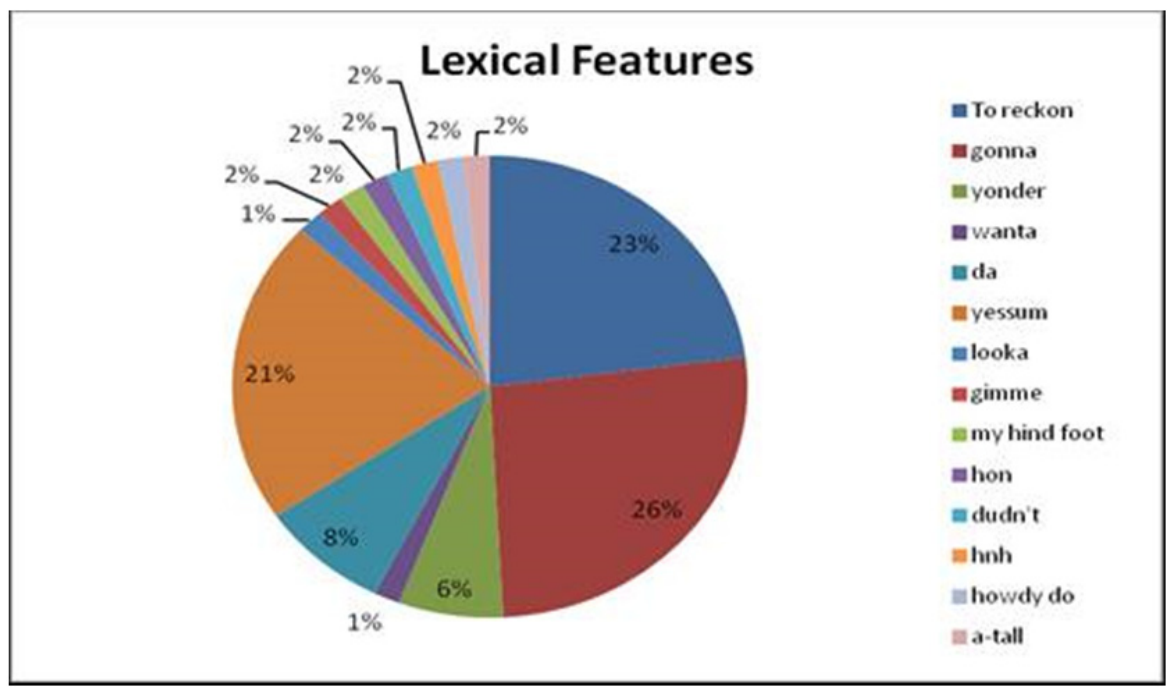

Fig.2. Lexical features of Southern American English on the example of the novel "Go Set a Watchman". 
This percentage reflects the frequency of use of the word's characteristic of the Southern dialect. Words like ain't, reckon, gonna, yessum, etc. are identifiers of this dialect.

Having considered the grammatical peculiarities of the dialect of the South based on the novel "Go set a Watchman", we can conclude that among the most common grammatical errors of the speakers of this dialect are 1) errors when asking a common question 2) correspondence of the tense forms of the verb and 3) omission of the auxiliary verbs in the questions.

\section{Conclusions}

The analyzed examples taken from the novels "To Kill a Mockingbird" [Deputatova and Biktagirova, 2015] and "Go set a Watchman" written by Harper Lee, helped us to see the specifics of the dialect of the South of the United States of America. We were able to compare the phonetic, grammatical and lexical features of the dialect with English literature and see huge differences. Considering this fact, we can assume that the worldview and personal experience of native speakers, as well as the perception of widely-known writers, can change over time and are purely a subjective point of view [Biktagirova and Deputatova, 2014]. A foreign language becomes an important and necessary element, both in systems of training and a guarantee of future successful scientific professional activity [Kondrateva and Nazarova, 2015].

\section{Acknowledgements}

The work is performed according to the Russian Government Program of Competitive Growth of Kazan Federal University.

\section{Refrences}

Akhmetova, L.A., Shaimardanova, M.R., Zorina, A.V., Nikishina, S.R., Nazmutdinova, M.A. \& Gatin, R.G. (2019). The word-formation category "displacement causation": mutational and modification semantics of German, Russian and Tatar verbs. XLinguae, Volume 12Issue 1, January2019, ISSN 1337-8384, elSSN 2453-711X. 2019 - p. 21-36.

Bernstein C. (2003). Grammatical Features of Southern speech: Yall, Might could, and fixin to. English in the Southern United States. Cambridge: Cambridge University Press. 203 p.

Biktagirova Z.A., Deputatova N.A. (2014). Comparative study of concepts "beauty/schonheit" (based on multipleresponse free associations of Americans and Germans) / Journal of Language and Literature. № $5(3)$ - p. 121-125.

Cassidy F., (2002). Houston Hall J. Dictionary of American Regional English. Cambridge, MA: Harvard University Press, $457 \mathrm{p}$.

Cheshire J. (2002). Variation in an English dialect. A sociolinguistic study. Cambridge: Cambridge University Press, $142 \mathrm{p}$.

Collins B.S., Mees E.M. (2013). Practical phonetics and Phonology: A Resource Book for Students. 3rd edition. Routledge, $330 \mathrm{p}$.

Deputatova N.A. Biktagirova Z.A. (2015). phonetic, grammatical and lexical features of southern american english on the example of "to kill a mockingbird" by harper lee // Journal of Language and Literature, ISSN: 2078-0303, Vol. 6. No. 2. p. 87-92

Hazen K., Fluharty E. Linguistic (2004). Diversity in the South: changing Codes, Practices and Ideology. University of Georgia Press, $141 \mathrm{p}$.

Herman L., Herman S. (1997). The New England Dialect. American Dialects: A Manual for Actors, Directors, and Writers. Routledge, $176 \mathrm{p}$.

Iravani, M. R., Niknejadi, F., \& Jahandoost, Z. (2015). The Relationship Between Age And Job Satisfaction Consultants Government Girls High School In Isfahan In 2012-2013 Academic Year. Health, 70(22.65), 24.

Kondrateva I.G., Nazarova M.V. (2015). integration of science and language in teaching english. Journal of Language and Literature, Vol.6, N 3, pp. $204-207$.

Labov W., Ash S., Boberg C. (2006). The Atlas of North American English. Berlin: Mouton-de Gruter, 237 p.

Lee H. (2015). Go Set a Watchman / H. Lee. - London.: Arrow Books, 278 p. 
Pussyrmanov, N., Rystina, I., Bulegenova, B., Askeyeva, G., \& Gabdulina, B. (2018). President Nursultan Nazarbayevs program article "The course towards future: Modernization of public consciousness"ideology, value and political aspects. Opción, 34(85-2), 824-837.

Singh, P., Teoh, S. H., Cheong, T. H., Md Rasid, N. S., Kor, L. K., \& Md Nasir, N. A. (2018). The Use of Problem-Solving Heuristics Approach in Enhancing STEM Students Development of Mathematical Thinking. International Electronic Journal of Mathematics Education, 13(3), $289-303$. https://doi.org/10.12973/iejme/3921

Yazdekhasti, A., Erfan, N., \& Nazari, N. (2015). Investigating the Relationship between Spiritual Intelligence and Social Adaptation among Girl High School Students in Shahreza City. UCT Journal of Social Sciences and Humanities Research, 3(1), 20-23. 